\title{
Dissolved and particulate primary production along a longitudinal gradient in the Mediterranean Sea
}

\author{
D. C. López-Sandoval, A. Fernández, and E. Marañón \\ Departamento de Ecología y Biología Animal, Universidad de Vigo, 36210 Vigo, Spain
}

Received: 5 November 2010 - Published in Biogeosciences Discuss.: 24 November 2010

Revised: 10 March 2011 - Accepted: 15 March 2011 - Published: 28 March 2011

\begin{abstract}
We have determined the photosynthetic production of dissolved (DOCp) and particulate organic carbon (POCp) along a longitudinal transect in the Mediterranean Sea during the summer stratification period. The euphotic layer-integrated rates of DOCp and POCp ranged between approximately $50-130$ and $95-210 \mathrm{mgC} \mathrm{m}^{-2} \mathrm{~d}^{-1}$, respectively, and showed an east to west increasing trend. For the whole transect, the relative contribution of DOCp to total, euphotic layer-integrated primary production (percentage of extracellular release, PER) averaged $\sim 37 \%$ and did not show any clear longitudinal pattern. In spite of the relatively high PER values, the measured DOCp rates were much lower than the estimated bacterial carbon demand, suggesting a small degree of coupling between phytoplankton exudation and bacterial metabolism. Our results, when compared with previous measurements obtained with the same methods in several ecosystems of contrasting productivity, support the view that the relative importance of DOCp increases under strong nutrient limitation.
\end{abstract}

\section{Introduction}

The production of dissolved organic carbon (DOCp), or dissolved primary production, is the fraction of the recently fixed carbon that is released to the extracellular medium in dissolved form. It represents a substantial fraction of total primary production (Baines and Pace, 1991; Nagata, 2000) and may be an important source of organic material to sustain heterotrophic bacterial growth (Cole et al., 1982; Fogg, 1983). The production of dissolved organic carbon by phytoplankton can be explained as a consequence of at least two, non-mutually exclusive mechanisms that can operate concur-

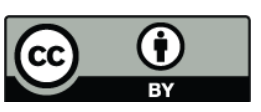

Correspondence to:

D. C. López-Sandoval

(daffne@uvigo.es) rently. Passive diffusion of low molecular weight compounds through the cellular membrane results in DOCp being persistent, whatever the growth conditions. However, a higher relative contribution of DOCp to total primary production could be expected when small cells dominate the community, due to their higher surface to volume ratio (Bjørnsen, 1988; Kiørboe, 1993). DOCp can also result from an active process that takes place when cells experience high light and nutrient stress. Under these conditions, phytoplankton tend to maintain their full photosynthetic capacity and, as a result, prevent photochemical damage and maximize their growth rate by eliminating any lag period for resuming carbon fixation when nutrients became available (Fogg, 1983; Wood and Van Valen, 1990). This latter mechanism could be particularly relevant in surface waters of oligotrophic regions. In these environments, the percentage of extracellular release $(\mathrm{PER}=100 \times \mathrm{DOCp} /(\mathrm{DOC} p+\mathrm{POCp}))$ represents between $\sim 20$ and $\sim 40 \%$ of total primary production (Fogg, 1983; Karl et al., 1998; Teira et al., 2001).

The Mediterranean Sea (MS) is a semi-enclosed basin which receives a continuous flow $(1 \sim \mathrm{Sv})$ from the Atlantic Ocean through the Gibraltar Strait (Béthoux and Gentili, 1999; Millot, 1999). The flow of nutrient-depleted, surface Atlantic water that enters the MS is counterbalanced by an outflow of relatively nutrient-enriched (Béthoux and CopinMontégut, 1986; Coste et al., 1988) intermediate and deep water (Millot and Taupier-Letage, 2005). This anti-estuarine circulation prevents an accumulation of regenerated nutrients in deeper layers, and, despite important atmospheric and terrestrial inputs, results in very low total nutrient concentrations, thus explaining the oligotrophic character of the basin (Azov, 1991; Krom et al., 1991, 2010).

The MS is characterized by a well-known west to east decrease in nutrient concentration, phytoplankton biomass and primary production (Moutin and Raimbault, 2002; Ignatiades et al., 2009). This W-E increase in oligotrophy is evident in ocean colour-based distributions of chlorophyll a

Published by Copernicus Publications on behalf of the European Geosciences Union. 
concentration (i.e. CSCZ, SeaWIFS) (Antoine et al., 1995; D’Ortenzio and Ribera d'Alcalá, 2009). Mean annual chlorophyll a concentrations, measured with SeaWIFS over a period of four years, ranged from 0.15 to $0.5 \mathrm{mg} \mathrm{m}^{-3}$ in most of the Western Basin (WB), with the exception of the Alboran region and the Tirrenian Sea, which in general shows the higher concentrations within the basin. The chlorophyll a concentrations detected within the Eastern Basin (EB) range between $0.04-0.08 \mathrm{mg} \mathrm{m}^{-3}$, the southern area being the most oligotrophic (Bosc et al., 2004). Primary production estimates range between $>100-250 \mathrm{gC} \mathrm{m}^{-2} \mathrm{y}^{-1}$ in the WB and $<65$ to $<250 \mathrm{gC} \mathrm{m}^{-2} \mathrm{y}^{-1}$ in the EB (Antoine et al., 1995; Bricaud et al., 2002). Lower values ( $163 \mathrm{gC} \mathrm{m}^{-2} \mathrm{y}^{-1}$ and $121 \mathrm{gC} \mathrm{m}^{-2} \mathrm{y}^{-1}$, respectively) were recently reported by Bosc et al. (2004).

Both satellite and in situ data collected across the MS shows that the seasonal cycle of algal biomass and particulate primary production generally describes a maximum during late winter or spring, due to the intense mixing and homogenization of the water column, and a minimum during the summer stratification period (Moutin and Raimbault, 2002; Bosc et al., 2004). High rates of POCp (>400 to $\sim 1000 \mathrm{mg} \mathrm{C} \mathrm{m}^{-2} \mathrm{~d}^{-1}$ ) are reported during the winter period in some regions of the WB (i.e. Gulf of Lion, Alborán Sea, Catalan Balearic region) (Morán and Estrada, 2001; Morán et al., 2001; Gaudy et al., 2003). During the stratification period, reported values range from $350-450 \mathrm{mgC} \mathrm{m}^{-2} \mathrm{~d}^{-1}$ for the WB to $150-\sim 400 \mathrm{mgC} \mathrm{m}^{-2} \mathrm{~d}^{-1}$ in the EB (Moutin and Raimbault, 2002).

While the spatial and temporal distribution of particulate primary production has been studied extensively in the MS, very few measurements of DOCp have been conducted. All the available information comes from the Western Basin, and the reported average PER values varies from 5-40\% (Fernández et al., 1994; Morán and Estrada, 2001; Morán et al., 2002; González et al., 2008). Therefore, little is known about the large-scale variability of DOCp along the Mediterranean Sea, its contribution to total primary production, and the extent to which dissolved primary production is coupled with bacterial production.

Here we report on measurements of POCp and DOCp conducted during the BOUM cruise (June-July 2008) in three different regions in the Mediterranean Sea: the Levantine Region, the Ionian Sea and the Algero Provençal Region. Our main objectives were: (i) to quantify the contribution of DOCp to the total primary production and its spatial variability along a longitudinal gradient, (Fuentes-Yaco et al.) to determine if PER changes depending on the productivity of the region and (iii) to assess the extent to which DOCp can sustain the demands of organic carbon to fuel bacterial production.

\section{Methods}

\subsection{Sampling}

Sampling was conducted during the BOUM (Biogeochemistry from the Oligotrophic to the Ultraoligotrophic Mediterranean Sea) cruise on board $\mathrm{R} / \mathrm{V}$ L' Atalante along an east to west transect from 16 June to 20 of July 2008. During the BOUM cruise, hydrological, biological and chemical variables were studied at 30 stations. Intensive, 4-day sampling was conducted in the Algero-Provençal basin (stations A), the Ionian Sea (stations B) and the Levantine basin (stations C). Sampling took place at the center of anticyclonic gyres, where horizontal advection was expected to be minimum. For a full description of the sampling strategy and the acquisition of complementary physical and chemical variables see Moutin et al. (2010).

\subsection{Inorganic nutrients and chlorophyll- $a$ concentration}

Concentration of $\mathrm{NO}_{3}, \mathrm{NO}_{2}$ and $\mathrm{PO}_{4}$ were measured on board using colorimetric techniques (Wood et al., 1967; Tréguer and Le Corre, 1975), while $\mathrm{NH}_{4}$ concentration was determined fluorometrically (Holmes et al., 1999), following the procedures detailed in Pujo-Pay et al. (2010). Chlorophyll- $a$ concentration was measured on board fluorometrically, according to Yentsch and Menzel (1963).

\subsection{Particulate and dissolved primary production}

For primary production experiments, water samples were taken at six fixed depths in the upper $200 \mathrm{~m}$ of the water column using a multi-sampler/carousel rosette system equipped with $12 \mathrm{~L}$ Niskin bottles. Sampling was conducted between 02:00 and 07:00 a.m. local time. Vertical profiles of primary production were obtained at 12 stations (Fig. 1), covering the Levantine Basin, the Ionian Sea and the AlgeroProvençal Basin. We carried out 6 in situ and 6 simulated in situ (SIS) incubations to determine the rates of dissolved (DOCp) and particulate (POCp) organic carbon production by phytoplankton. SIS incubations were done in an on-deck incubator equipped with a set of blue and neutral density filters that reproduced six different light levels from $100 \%$ to $1 \%$, to ensure we incubated samples approximately under the irradiance level that was recorded at the sampling depth. All incubators were cooled by recirculating surface water.

Immediately after collection of seawater samples from each sampling depth, three light and two dark acid-washed, polystyrene cell culture bottles $(70 \mathrm{~mL})$ were filled with the sample, spiked with $10-20 \mu \mathrm{Ci}$ of $\mathrm{NaH}^{14} \mathrm{CO}_{3}$, and incubated for $24 \mathrm{~h}$. At the end of the incubation period, two 5-mL aliquots from each incubation bottle were filtered through $0.2-\mu \mathrm{m}$ polycarbonate (PC) filters ( $25 \mathrm{~mm}$ in diameter) using low vacuum pressure $(<50 \mathrm{~mm} \mathrm{Hg})$. After being acidified to 


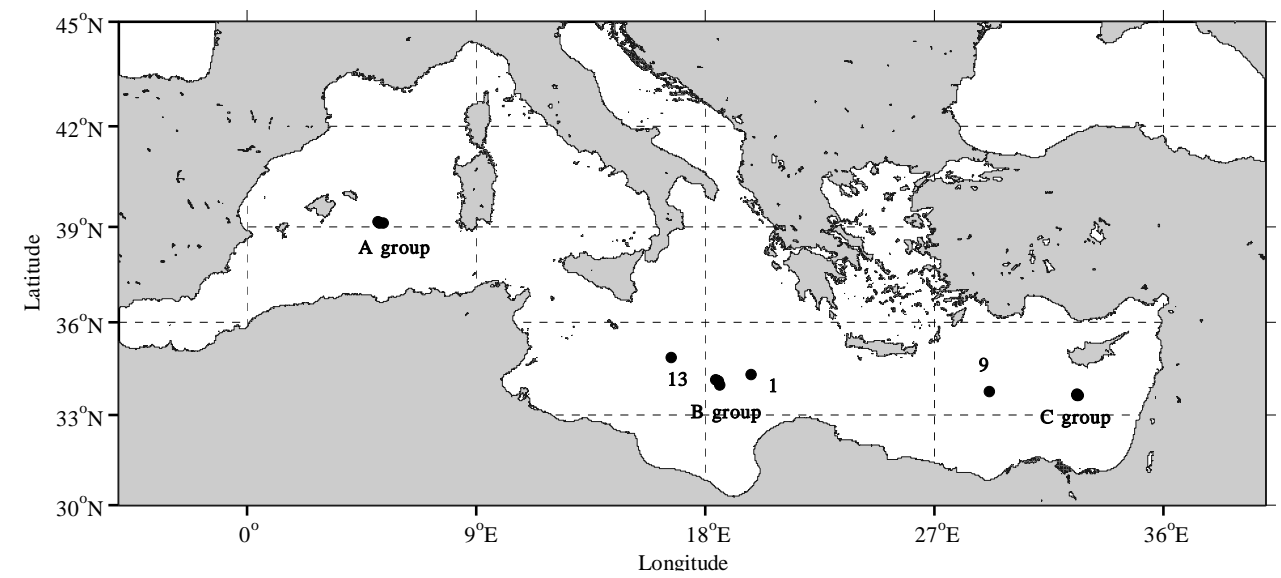

Fig. 1. Map of the sampled stations. POCp and DOCp measurements were conducted in a total of 12 stations along the BOUM transect. Three stations were occuppied inside the anticyclonic eddies sampled in each region (A, B, C), two in the Ionian Sea, and one in the Levantine basin.

a pH of $\sim 2$ with $100 \mu \mathrm{L}$ of $50 \% \mathrm{HCl}$, filtrates were maintained overnight in open scintillation vials $(20 \mathrm{~mL})$ placed on an orbital shaker. After inorganic ${ }^{14} \mathrm{C}$ removal, $15 \mathrm{~mL}$ of a high-sample capacity scintillation cocktail were added to each filtrate. The inorganic ${ }^{14} \mathrm{C}$ present in the filters was removed by exposing them to concentrated $\mathrm{HCl}$ fumes for $12 \mathrm{~h}$. The filters were then placed in scintillation vials $(4 \mathrm{~mL})$ to which $3.4 \mathrm{~mL}$ of Packard Ultima Gold XR scintillation cocktail were added. The radioactivity on each sample was determined on a Tri-Carb 3100TR scintillation counter. To calculate the rates of DOC and POC production, the black bottle DPM's (disintegrations per minute) were subtracted from the light bottle DPM's. We used a value of $25700 \mathrm{mgC} \mathrm{m}^{-3}$ for the concentration of dissolved inorganic carbon and a value of 1.05 for the isotopic discrimination factor. We are aware that a substantial heterotrophic consumption of DOC (on average, 30-50\%) (Fernández et al., 1994; Morán and Estrada, 2002) might take place during the incubation period. For this reason, the results we report must be regarded as net DOC production rates.

\subsection{Bacterial carbon demand}

Bacterial carbon demand (BCD) was calculated by adding the measured bacterial production rates (BP) (Van Wambeke et al., 2010) and estimates of bacterial respiration (BR). In order to compute $\mathrm{BR}$, the amount of new bacterial biomass produced per unit of organic $C$ substrate assimilated [bacterial growth efficiency, $\mathrm{BGE}=\mathrm{BP} /(\mathrm{BP}+\mathrm{BR})]$, was estimated with two different models. The first model used is based on bacterial production (del Giorgio and Cole, 1998):

$\mathrm{BGE}=(0.037+0.65 \mathrm{BP}) /(1.8+\mathrm{BP})$
The second model is based on chlorophyll- $a(\mathrm{Chl}-a)$ concentration as a proxy for resource availability (LópezUrrutia and Morán, 2007):

$\mathrm{BGE}=1-[1 /(0.727 \times[\mathrm{Chl}-a /(\mathrm{Chl}-a+4.08)]+1.02)](2)$

\section{Results}

\subsection{General oceanographic setting}

During the BOUM cruise, the west to east increase in oligotrophy that characterizes the Mediterranean Sea was observed. Sea surface temperature ranged between $<24^{\circ} \mathrm{C}$ in the western basin to $>26^{\circ} \mathrm{C}$ in the eastern side (Moutin et al., 2010). Nutrient concentrations were close to the detection limit in the upper layers (above the top of the termocline), being higher on the western side of the basin (PujoPay et al., 2010), where higher pigment concentrations and primary production rates were also observed. A deep chlorophyll maximum (DCM) was observed throughout the study (Crombet et al., 2010). The DCM was located near the base of the euphotic zone (1\% photosynthetically active radiation, PAR), and its value ranged from $>0.5 \mathrm{mg} \mathrm{Chl}-a \mathrm{~m}^{-3}$ in the most western stations to $<0.5 \mathrm{mg} \mathrm{Chl}-a \mathrm{~m}^{-3}$ in the Levantine region. Overall, the west to east gradient was also observed in terms of bacterial production, heterotrophic bacterial biomass, and abundance of viruses and heterotrophic nanoflagellates (Christaki et al., 2010).

Inside the antyciclonic gyres, the depth of the euphotic zone was on average $83 \mathrm{~m}$ in the western stations (A group), $103 \mathrm{~m}$ in the stations sampled in the Ionian Sea (B group), and $102 \mathrm{~m}$ for the stations sampled in the Levantine region (C group) (Moutin et al., 2010). For the whole cruise, the relative contribution of picophytoplankton $(0.2-2 \mu \mathrm{m}$ in 

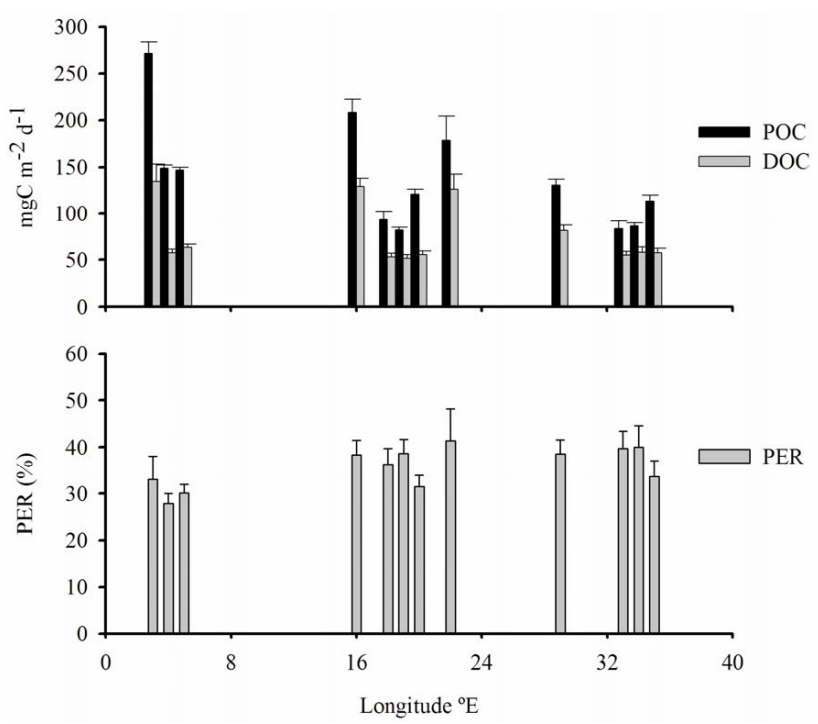

Fig. 2. Euphotic layer-integrated rates of particulate (POCp) and dissolved (DOCp) organic carbon production $\left(\mathrm{mgC} \mathrm{m}^{-2} \mathrm{~d}^{-1}\right)$ and the percentage of extracellular release (PER) along a longitudinal gradient in the Mediterranean Sea.

diameter) and $>2 \mu \mathrm{m}$ phytoplankton to total phytoplankton biomass, as estimated from Chl- $a$, was $56 \%$ and $44 \%$, respectively. These differences were statistically significant (Mann-Whitney $U$-test, $n=8, P=0.04$ ). The differences between the three regions in the biomass contribution from each size class were not statistically significant (Kruskal-Wallis $H$-test, $n=8, P=0.1, P=0.1$, respectively).

\subsection{Primary production along the longitudinal gradient}

The longitudinal gradient along the MS showed a slight increase in production rates, from east to west, in both dissolved (DOCp) and particulate (POCp) primary production, and a decrease in the percentage of extracellular release (PER) (Fig. 2). Mean POCp rates varied from $189(\mathrm{SD}, 72) \mathrm{mgC} \mathrm{m}^{-2} \mathrm{~d}^{-1}$ in region $\mathrm{A}$ to 95 (SD, 16) $\mathrm{mgC} \mathrm{m}^{-2} \mathrm{~d}^{-1}$ in region $\mathrm{C}$, while DOCp changed from $85(\mathrm{SD}, 43) \mathrm{mgC} \mathrm{m}^{-2} \mathrm{~d}^{-1}$ to $57(\mathrm{SD}, 1) \mathrm{mgC} \mathrm{m}^{-2} \mathrm{~d}^{-1}$, respectively (Table 1). Total production (POCp + DOCp) measured in the Eastern Basin inside the anticyclonic gyres (region $\mathrm{B}, \mathrm{C}$ ), was $\sim 150 \mathrm{mgC} \mathrm{m}^{-2} \mathrm{~d}^{-1}$ while a rate of $274 \mathrm{mgC} \mathrm{m}^{-2} \mathrm{~d}^{-1}$ was measured the Algero Provençal area (region A). In the Eastern Basin, outside the antyciclonic gyres, total production rates were $>300 \mathrm{mgC} \mathrm{m}^{-2} \mathrm{~d}^{-1}$ in the Ionian Sea (stations 1 and 13) and $212 \mathrm{mgC} \mathrm{m}^{-2} \mathrm{~d}^{-1}$ in the Levantine Basin (station 9) (Table 1). When we compared vertical integrated production rates $\left(\mathrm{mgC} \mathrm{m}^{-2} \mathrm{~d}^{-1}\right)$ inside the anticyclonic gyres (regions A, B, C), POCp and DOCp rates were not significantly different between them (KruskalWallis H-test, $n=9, P=0.07, P=0.09$, respectively).
Primary production rates (DOCp and POCp) inside the anticyclonic gyres were characterized by a general decrease in production rates with depth, especially in two of the three profiles measured in region A (Fig. 3). Surface POCp rates ranged between $2.5 \mathrm{mgC} \mathrm{m}^{-3} \mathrm{~d}^{-1}$ in the WB and $<1.5 \mathrm{mgC} \mathrm{m}^{-3} \mathrm{~d}^{-1}$ in the EB, while DOCp rates ranged between $1.2 \mathrm{mgC} \mathrm{m}^{-3} \mathrm{~d}^{-1}$ and $<0.5 \mathrm{mgC} \mathrm{m}^{-3} \mathrm{~d}^{-1}$, respectively. In general, DOCp and POCp tended to covariate within the water column. No clear pattern was observed in the vertical variability of PER profiles (Fig. 3), and the mean PER in the water column varied from $30 \%$ in the group A stations to $37 \%$ for group C; nevertheless, no statistical difference was found between the groups (Kruskal-Wallis H-test, $n=9, P=0.09$ ) (Table 1), indicating that, overall, the contribution of DOCp to total primary production was relatively constant throughout the studied area. When possible, our volumetric POCp data were compared with POCp data measured at the same stations with the standard JGOFS protocol (Lagaria, pers. comm.). A highly significant correlation between the two types of measurements was found ( $r^{2}=0.59, P<0.001, n=34$, data not shown). On a small number of samples, POCp estimates obtained with the JGOFS protocol were higher than those obtained with our method, which measures both POCp and DOCp. However, PER values in these samples were not any higher than those measured in the other samples, which suggests that the occasional discrepancy between the two techniques was not a result of an overestimate of DOCp by our method.

\subsection{Relationship between particulate and dissolved primary production}

The consistency in the relative contribution of dissolved primary production in our study was confirmed when the $\log -\log$ relationship between the integrated and volumetric rates of DOCp and POCp were compared across all stations. A highly significant correlation was found between the logarithms of POCp and DOCp rates, both with volumetric $\left(r^{2}=0.84, P<0.001, n=69\right.$, Fig. $\left.4 a\right)$ and integrated data $\left(r^{2}=0.74, P<0.001, n=12\right.$, Fig. $\left.4 \mathrm{~b}\right)$. The slope of the regression line (Model II), in both cases, was not significantly different from 1 (Clarke test, $P=0.42$ and $P=0.97$, respectively), indicating that the relative contribution of DOCp to total production (POCp + DOCp) did not change across the range of measured POCp. On average, the relative contribution of DOCp to total, euphotic layerintegrated primary production in our study was $37 \%(\mathrm{SD}, 4)$.

In an attempt to relate the percentage of extracellular release to the changes in the size structure or changes in the taxonomic composition of the phytoplankton assemblages sampled, all volumetric values of PER were plotted against the percentage of Chl- $a$ measured in the 0.2$2.0 \mu \mathrm{m}$ and $>2.0 \mu \mathrm{m}$ size classes (data not shown) and against the mean biomass contribution of different phytoplankton groups on each station. We did not find any relationship 
Table 1. Mean values of surface temperature $\left({ }^{\circ} \mathrm{C}\right)$, chlorophyll a concentration $(\mathrm{Chl}-a)$ at the deep chlorophyll maximum $(\mathrm{DCM})$, vertically integrated particulate (POCp) and dissolved primary production (DOCp), the percentage of extracellular release (PER), and total integrated primary production rates $(\mathrm{PP})$.

\begin{tabular}{|c|c|c|c|c|c|c|}
\hline Station & Temperature & $\begin{array}{r}\text { DCM Chl- } a \\
\left(\mathrm{mg} \mathrm{m}^{-3}\right)\end{array}$ & $\begin{array}{r}\text { POCp } \\
\left(\mathrm{mgC} \mathrm{m}^{-2} \mathrm{~d}^{-1}\right)\end{array}$ & $\begin{array}{r}\text { DOCp } \\
\left(\mathrm{mgC} \mathrm{m}^{-2} \mathrm{~d}^{-1}\right)\end{array}$ & $\begin{array}{r}\text { PER } \\
(\%)\end{array}$ & $\begin{array}{r}\text { Total PP } \\
\left(\mathrm{mgC} \mathrm{m}^{-2} \mathrm{~d}^{-1}\right)\end{array}$ \\
\hline Region A $(n=3)$ & $24.7(0.3)$ & $0.63(0.15)$ & $189(72)$ & $85(43)$ & 30 & 274 \\
\hline Stn 13 & 26.7 & 0.26 & 208 & 130 & 38 & 338 \\
\hline Region B $(n=3)$ & $26.6(0.3)$ & $0.23(0.08)$ & $99(20)$ & $54(2)$ & 35 & 152 \\
\hline Stn 1 & 24.2 & 0.71 & 178 & 126 & 41 & 304 \\
\hline Stn 9 & 24.4 & 0.28 & 130 & 82 & 39 & 212 \\
\hline Region C $(n=3)$ & $26.2(0.1)$ & $0.56(0.17)$ & $95(16)$ & $57(1)$ & 38 & 151 \\
\hline
\end{tabular}

Standard deviation is indicated in parenthesis.

between PER and the size-partitioning of Chl- $a$ nor between PER and the relative abundance of different phytoplankton groups (Synechococcus, Prochlorococcus, picoeukaryotes, nanophytoplankton and microphytoplankton).

\subsection{Dissolved primary production and bacterial carbon demand (BCD)}

To explore if DOCp was an important source of organic matter for bacterial consumption, bacterial carbon demand (BCD) was calculated with different algorithms (see details in Methods). There was a significant correlation between the logarithms of DOCp and BCD obtained with bacterial growth efficiency (BGE) estimates based on bacterial production $\left(r^{2}=0.45, P<0.001, n=68\right.$ ) (del Giorgio and Cole, 1998) (Fig. 5a) and with the model based on Chl-a concentration $\left(r^{2}=0.50, P<0.001, n=48\right.$ ) (López-Urrutia and Morán, 2007) (Fig. 5b). However, in spite of the variability of BCD explained by DOCp (45\% with the model proposed by Del Giorgio and Cole or $50 \%$ with the model proposed by López-Urrutia and Morán), which might suggest a certain degree of coupling between phytoplankton production and bacterial consumption, BCD was always considerably larger than the actual supply of dissolved compounds released by phytoplankton, irrespective of the model used to estimate BCD (Fig. 5a, b).

\section{Discussion}

\subsection{Particulate and dissolved primary production}

The Mediterranean Sea is often described as a system with a characteristic transition from oligotrophic conditions in the western basin to ultraoligotrophic conditions in the eastern basin. The region presents a marked seasonality, which determines the variability in primary production. During winter, when the Mistral wind begins, cooling of surface waters produces an intense mixing of the water column (Killworth, 1976), which brings nutrients from deep to surface layers and allows the development of phytoplankton blooms (Morel and André, 1991; Estrada, 1996). Low production rates are a common feature of the summer period in the MS. During this season, strong thermal stratification conditions prevail and nutrients become depleted in the upper layers (Marty et al., 2002), as observed during the BOUM cruise (Pujo-Pay et al., 2010).

The particulate production rates measured during this cruise were similar to those reported by Moutin and Raimbault (2002). Dissolved primary production remained quite constant, and represented $\sim 37 \%$ of total primary production along the gradient measured in the MS. Although, little information is available to compare our results with, and all existing data mostly come from the Western Basin (Fernández et al., 1994; Morán and Estrada, 2001; Morán et al., 2002; Alonso-Sáez et al., 2008), our results are within the range of PER values reported in the previous studies.

\subsection{Variability in the contribution of dissolved primary production}

It is often stated that DOCp gains importance under nutrient limited conditions (Fogg, 1983). In laboratory cultures, an increase in the relative importance of exudation has been observed in nutrient limited cells (Myklestad, 1977; Lancelot, 1983; Obernosterer and Herndl, 1995; Borsheim et al., 2005). In oligotrophic environments, high PER values (Thomas, 1971; Karl et al., 1998; Teira et al., 2001) and significant correlations between PER and the relative contribution of small cells have been reported (Teira et al., 2001; Morán et al., 2002). In spite of the high PER values found in this work $(>35 \%)$, and the fact that the higher contribution to phytoplankton biomass was mainly due to pico and nanophytoplankton, we did not find any association between PER and the relative contribution to biomass of the different phytoplankton groups, which is consistent with previous analyses (Marañón et al., 2004; López-Sandoval et al., 2010). There are physiological reasons to expect an effect of phytoplankton size structure on the relative contribution of DOCp 


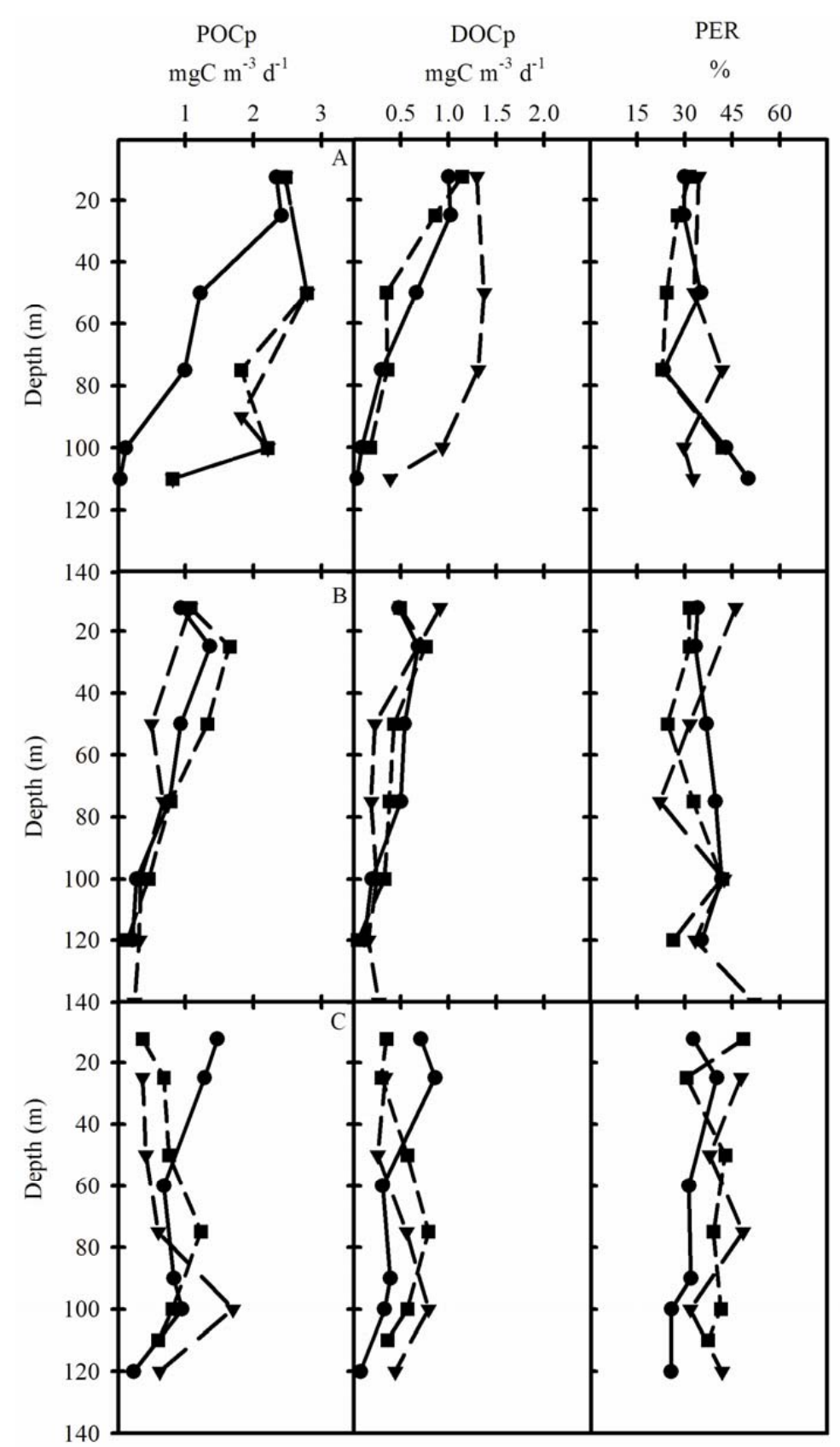

Fig. 3. Vertical profiles of DOCp, POCp $\left(\mathrm{mgC} \mathrm{m}^{-3} \mathrm{~h}^{-1}\right)$, and PER from the stations sampled at regions A (Algero Provençal eddy), B (Ionian eddy) and C (Levantine eddy).

to total primary production. The increased surface to volume ratio of small cells should favor the passive diffusion of small molecular weight compounds through the cell membrane (Bjørnsen, 1988; Kiørboe, 1993). Nevertheless, the high PER values may also be the result of keeping the cellular machinery active when cells cannot complete the synthesis of macromolecules due to very low nutrient concentrations, characteristic of a system like the Mediterranean Sea, which limits phytoplankton production and growth. Further- more, it has been reported that the exudation rate of DOC by phytoplankton under P-limiting conditions, such as the ones found in the Mediterranean Sea (Krom et al., 1991, 2010; Pujo-Pay et al., 2010), become more important than under N-limited conditions (Myklestad and Haug, 1972; Obernosterer and Herndl, 1995). The increase of DOCp rates as the $N: P$ ratio increases might lead to an accumulation of the photosynthetically derived dissolved organic matter in surface waters of oliogotrophic areas (Karl et al., 1998). 

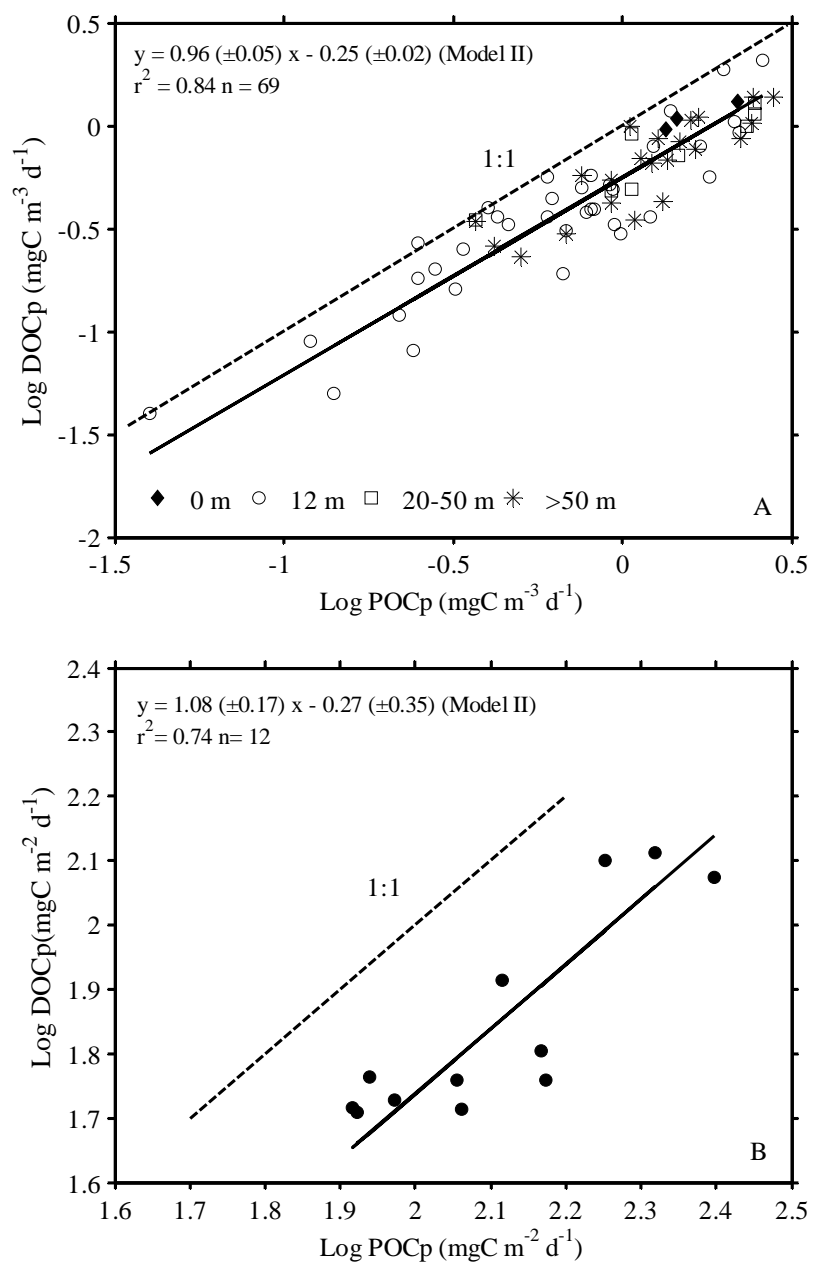

Fig. 4. Log-log relationship between particulate (POCp) and dissolved organic carbon production (DOCp) with all pooled (A) volumetric and (B) euphotic layer-integrated measurements. In both (A) and (B), the slope of the regression line was not significantly different from 1 (Clarke test, $P=0.42$ and 0.97 for volumetric and integrated data, respectively).

\subsection{Dissolved primary production in contrasting environments}

The early perception that DOCp is not an important fraction of primary production, at least in productive waters such as coastal regions (Thomas, 1971; Fogg, 1983), has resulted in that DOCp measurements are not carried out in many surveys of marine productivity. Baines and Pace (1991), in their review of 16 studies including lacustrine, marine and estuarine observations, concluded that the percentage of extracellular release represented $13 \%$ of total carbon fixation. However, PER data from both productive ( $\sim 20 \%$, reported by Marañón et al., 2004) and oligotrophic areas such as the MS (PER $>35 \%$ in this work; $32 \%$ reported by Fernández et al. (1994), >40\% reported by Pugnetti et al. (2005), and values up to $45 \%$ reported by Alónso-Sáez et al. (2008)) or

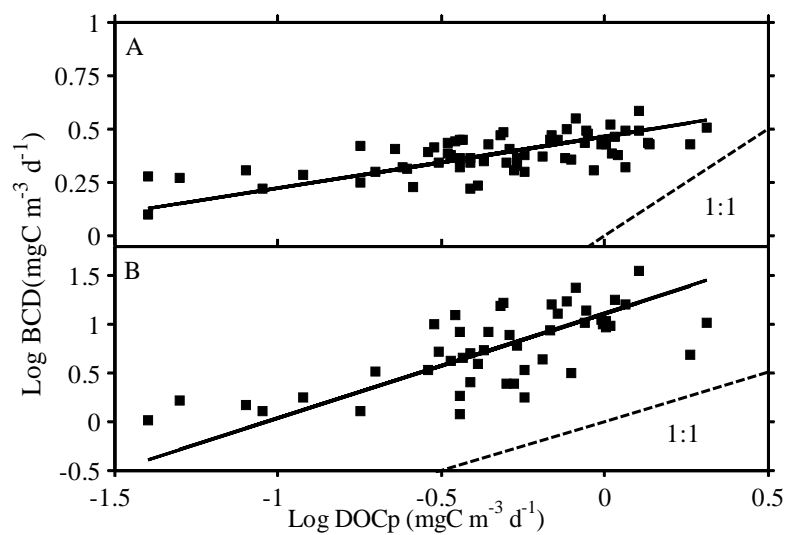

Fig. 5. Relationship between DOCp and bacterial carbon demand (BCD). To compute $\mathrm{BCD}$, bacterial growth efficiency was estimated with the models of (A) del Giorgio and Cole (1998) and (B) López-Urrutia and Morán (2007). See methods for details.

the Sargasso Sea (44\%) (Thomas, 1971), demonstrate that DOCp represents an important fraction of total production rates in all pelagic ecosystems. The lower PER value estimated by Baines and Pace (1991) may have been in part the result of the few marine and oligotrophic data that were included in the review, as well as methodological problems such as the use of glass fiber filters in DOCp measurements. It is now known that the use of glass fiber filters may lead to serious underestimations of DOCp rates since an important part of dissolved organic compounds tends to be adsorbed by these filters (Maske and García-Mendoza, 1994; Karl et al., 1998; Morán et al., 1999).

It is worthwhile noting that when the variability in DOCp is analysed within the same ecosystem, the percentage of extracellular release tends to remain rather constant both over space (as shown in the present study) and also over time, including seasonal and weekly scales (Marañón et al., 2004; López-Sandoval et al., 2010). If we consider a larger data set which includes vertically integrated data from widely contrasting environments (an ultraoligotrophic region, a temperate sea and a highly productive system) (Fig. 6), the slope obtained from the log-log regression line between DOCp and POCp is not significantly lower than 1 (Clarke test, $P=0.177)$. This result implies that with this data set, no overall inverse relationship between PER and total primary production exists. Nevertheless, it is necessary to take into account that few data from very oligotrophic conditions were included $(n=12)$. Furthermore, the results obtained during the BOUM cruise showed that there is an increasing contribution of DOCp in oligotrophic ecosystems, as suggested in earlier studies (Anderson and Zeutschel, 1970; Thomas, 1971; Berman and Holm-Hansen, 1974; Mague et al., 1980; Fogg, 1983), and more recently reported by Teira et al. (2001) and Morán et al. (2002). This pattern may be related to the mechanisms involved in DOC exudation. 


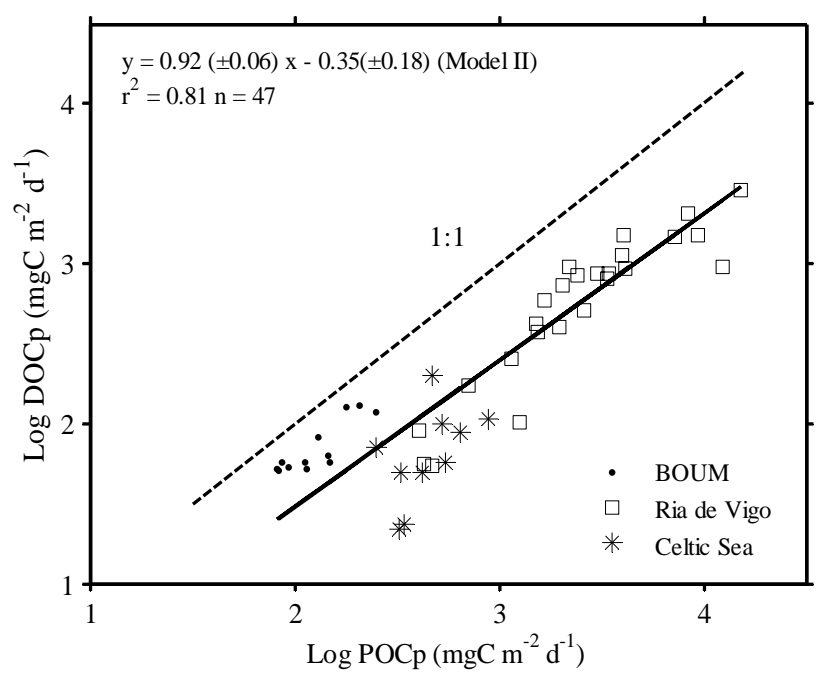

Fig. 6. Relationship between particulate (POCp) and dissolved organic carbon production (DOCp) with vertically integrated data from different ecosystems: The Mediterranean Sea (BOUM cruise, this study), NW Iberian Peninsula (Marañón et al., 2004), and the Celtic Sea (Marañón et al. 2005). The slope of the regression line for the overall dataset was not significanlty different from 1 (Clarke test, $P=0.177)$.

There is evidence suggesting that DOC release is a passive diffusion process, which is not directly related to the phytoplankton community structure (Marañón et al., 2004; LópezSandoval et al., 2010), can be enhanced under suboptimal conditions (Morán and Estrada, 2001; Marañón et al., 2004, 2005), and is persistent as long as there is an internal pool of recently synthesized metabolites (Mague et al., 1980). However, when data taken under extreme oligotrophic conditions are considered, it seems that DOC exudation may also be a mechanism to compensate the uncoupling between high energy (light) and low nutrients. This is likely to be an adaptation process that not only prevents photochemical damage, but also avoids the lag period to resume carbon fixation when nutrients become again available (Fogg, 1983; Wood and Van Valen, 1990).

\subsection{Coupling between dissolved primary production and bacterial production}

Our results showed that, irrespective of the model used to calculate bacterial growth efficiency (BGE), there was always a clear excess (5 to 14-fold) of bacterial carbon demand (BCD) over DOCp. The BGE values calculated with the two models (2-26\%) are within the range reported for the NW Mediterranean Sea (DYFAMED station) during summer conditions (Lemée et al., 2002), and by Alónso-Sáez et al. (2008) during a monthly study (2001-2006) in Blanes Bay. The fact that phytoplankton DOCp was not able to supply all the carbon required by bacterial community has of- ten been reported in the MS (Fernández et al., 1994; Van Wambeke et al., 2001; Pugnetti et al., 2005; Alonso-Sáez et al., 2008), and suggest that additional DOC inputs, not belonging to the pool of recently photosynthesized matter, are needed to sustain bacterial production.

It has been shown that when phytoplankton experience P-limitation of growth, such as is the case over large expanses of the Mediterranean Sea, exudation rates tend to increase (Obernosterer and Herndl, 1995). However, the quality of the released material may in turn affect the efficiency with which bacteria can use the dissolved substrates, and their metabolism can therefore be affected by the same Plimitation (Puddu et al., 2003). Low bacterial metabolic activity, due to poor quality of the material available, might lead to an accumulation of DOC in surface waters. This accumulation of DOC, which takes place in the MS during the summer (Copin-Montégut and Avril, 1993; Thingstad et al., 1998), has also been suggested as a P-limitation indicator in the North Pacific subtropical gyre (Karl et al., 1998).

The fact that the BCD estimated in this work was higher than the DOCp rates measured, suggest that there are other significant sources of labile DOC controlled by multiple trophic mechanisms. Phytoplankton cell lysis induced by viruses, or DOC released from grazers by egestion, excretion or incomplete cell consumption, can also be important supplies of dissolved organic matter for bacteria (Nagata, 2000). In oligotrophic environments, it is well known that the phytoplankton community is mostly dominated by small cells (Chisholm, 1992; Raven, 1998), which in turn are under tight grazing control by unicellular protists, as reported by Hagström et al. (1988) for the MS. Therefore, it is likely that grazing activity represents an important source of labile DOC ready to be consumed by heterotrophic bacteria.

\section{Conclusions}

Dissolved primary production is a relatively constant process in the Mediterranean Sea during the summer stratification period, represents an important fraction of total primary production (37\% on average) and does not seem to be related to phytoplankton biomass or community structure. Although DOCp remained largely constant along the observed productivity gradient, when data from contrasting environments were compared a higher relative contribution of DOCp in very oligotrophic conditions was observed. DOCp was always much lower than bacterial carbon demand, indicating that additional sources of DOC are needed to sustain bacterial production in the Mediterranean Sea during summer oligotrophic conditions.

Acknowledgements. We are grateful to T. Moutin for giving us the opportunity to contribute to the BOUM project, as well as for his comments on an earlier version of the manuscript. We also thank A. Lagaria and S. Psarra for giving access to the primary production and size-fractionated chlorophyll- $a$ data, and 
F. Van Wambeke for giving access to the bacterial production data. Our participation in the BOUM cruise was made possible by a "Complementary Action" grant from the Spanish Ministry of Science and Innovation (MICINN) (grant CTM2007-31097E/MAR to E. M.). This research has also been funded by MICINN through the research project "Macroecological patterns in marine phytoplankton" (grant CTM2008-03699 to E. M.). D.C.L.S was supported by a postgraduate fellowship from the Mexican Council of Science and Technology (CONACyT).

Edited by: P. T. Moutin

\section{References}

Alonso-Sáez, L., Vázquez-Domínguez, E., Cardelús, C., Pinhassi, J., Sala, M., Lekunberri, I., Balagué, V., Vila-Costa, M., Unrein, F., Massana, R., Simó, R., and Gasol, J.: Factors controlling the year-round variability in carbon flux through bacteria in a coastal marine system, Ecosystems, 11, 397-409, 2008.

Anderson, G. C. and Zeutschel, R. P.: Release of dissolved organic matter by marine phytoplankton in coastal and offshore areas of the Northeast Pacific Ocean, Limnol. Oceanogr., 15, 402-407, 1970.

Antoine, D., Morel, A., and André, J.-M.: Algal pigment distribution and primary production in the eastern Mediterranean as derived from coastal zone color scanner observations, J. Geophys. Res., 100, 16193-16209, doi:10.1029/95jc00466, 1995.

Azov, Y.: Eastern Mediterranean- a marine desert?, Mar. Pollut. Bull., 23, 225-232, 1991.

Baines, S. B. and Pace, M. L.: The production of dissolved organic matter by phytoplankton and its importance to bacteria patterns across marine and freshwater systems, Limnol. Oceanogr., 36, 1078-1090, 1991.

Berman, T. and Holm-Hansen, O.: Release of photoassimilated carbon as dissolved organic matter by phytoplankton, Mar. Biol., 28, 305-310, 1974.

Béthoux, J. P. and Copin-Montégut, G.: Biological fixation of atmospheric nitrogen in the Mediterranean Sea, Limnol. Oceanogr., 31, 1353-1358, 1986.

Béthoux, J. P. and Gentili, B.: Functioning of the Mediterranean Sea: past and present changes related to freshwater input and climate changes, J. Marine Syst., 20, 33-47, 1999.

Bjørnsen, P. K.: Phytoplankton exudation of organic matter: Why do healthy cells do it?, Limnol. Oceanogr., 33, 151-154, 1988.

Borsheim, K. Y., Vadstein, O., Myklestad, S. M., Reinertsen, H., Kirkvold, S., and Olsen, Y.: Photosynthetic algal production, accumulation and release of phytoplankton storage carbohydrates and bacterial production in a gradient in daily nutrient supply, J. Plankton Res., 27, 743-755, 2005.

Bosc, E., Bricaud, A., and Antoine, D.: Seasonal and interannual variability in algal biomass and primary production in the Mediterranean Sea, as derived from 4 years of SeaWiFS observations, Global Biogeochem. Cy., 18, GB1005, doi:10.1029/2003gb002034, 2004.

Bricaud, A., Bosc, E., and Antoine, D.: Algal biomass and sea surface temperature in the Mediterranean Basin - Intercomparison of data from various satellite sensors, and implications for pri- mary production estimates, Remote Sens. Environ., 81, 163-178, 2002.

Cole, J. J., Likens, G. E., and Strayer, D. L.: Photosynthetically produced dissolved organic-carbon an important carbon source for planktonic bacteria, Limnol. Oceanogr., 27, 1080-1090, 1982.

Copin-Montégut, G. and Avril, B.: Vertical distribution and temporal variation of dissolved organic carbon in the North-Western Mediterranean Sea, Deep Sea Research Part I: Oceanographic Research Papers, 40, 1963-1972, 1993.

Coste, B., Corre, P. L., and Minas, H. J.: Re-evaluation of the nutrient exchanges in the strait of gibraltar, Deep Sea Research Part A. Oceanographic Research Papers, 35, 767-775, 1988.

Crombet, Y., Leblanc, K., Quéguiner, B., Moutin, T., Rimmelin, P., Ras, J., Claustre, H., Leblond, N., Oriol, L., and Pujo-Pay, M.: Deep silicon maxima in the stratified oligotrophic Mediterranean Sea, Biogeosciences Discuss., 7, 6789-6846, doi:10.5194/bgd7-6789-2010, 2010.

Chisholm, S. W.: Phytoplankton Size, in: Primary productivity and biogeochemical cycles in the sea, edited by: Falkowski, P. G., and Woodhead, A. D., Plenum, New York, USA, 213-237, 1992.

Christaki, U., Van Wambeke, F., Lefevre, D., Lagaria, A., Prieur, L., Pujo-Pay, M., Grattepanche, J. D., Colombet, J., Psarra, S., Dolan, J. R., Sime-Ngando, T., Conan, P., Weinbauer, M. G., and Moutin, T.: The impact of anticyclonic mesoscale structures on microbial food webs in the Mediterranean Sea, Biogeosciences Discuss., 8, 185-220, doi:10.5194/bgd-8-185-2011, 2010.

D'Ortenzio, F. and Ribera d'Alcalá, M.: On the trophic regimes of the Mediterranean Sea: a satellite analysis, Biogeosciences, 6, 139-148, doi:10.5194/bg-6-139-2009, 2009.

del Giorgio, P. A. and Cole, J. J.: Bacterial growth efficiency in natural aquatic systems, Annu. Rev. Ecol. Syst., 29, 503-541, 1998.

Estrada, M.: Primary production in the northwestern Mediterranean, Sci. Mar., 60, 55-64, 1996.

Fernández, M., Bianchi, M., and Van Wambeke, F.: Bacterial biomass, heterotrophic production and utilization of dissolved organic matter photosynthetically produced in the Almeria-Oran front, J. Marine Syst., 5, 313-325, 1994.

Fogg, G. E.: The ecological significance of extracellular products of phytoplankton photosynthesis, Bot. Mar., XXVI, 3-14, 1983.

Fuentes-Yaco, C., Devred, E., Sathyendranath, S., Platt, T., Payzant, L., Caverhill, C., Porter, C., Maass, H., and White III, G. N.: Comparison of in situ and remotely sensed (SeaWIFS) chlorophyll-a in the Northwest Atlantic, Indian J. Mar. Sci., 34, 341-355, 2005.

Gaudy, R., Youssara, F., Diaz, F., and Raimbault, P.: Biomass, metabolism and nutrition of zooplankton in the Gulf of Lions (NW Mediterranean), Oceanol. Acta, 26, 357-372, 2003.

González, N., Gattuso, J. P., and Middelburg, J. J.: Oxygen production and carbon fixation in oligotrophic coastal bays and the relationship with gross and net primary production, Aquat. Microb. Ecol., 52, 119-130, 2008.

Hagström, Å., Azam, F., Andersson, A., Wikner, J., and Rassoulzadegan, F.: Microbial loop in an oligotrophic pelagic marine ecosystem: possible roles of cyanobacteria and nanoflagellates in the organic fluxes, Mar. Ecol. Prog. Ser., 49, 171-178, 1988.

Holmes, R. M., Aminot, A., Kérouel, R., Hooker, B. Z., and Peterson, B. J.: A simple and precise method for measuring 
ammonium in marine and freswater ecosystems., Can. J. Fis. Aquat. Sci., 56, 1801-1808, 1999.

Ignatiades, L., Gotsis-Skretas, O., Pagou, K., and Krasakopoulou, E.: Diversification of phytoplankton community structure and related parameters along a large-scale longitudinal east-west transect of the Mediterranean Sea, J. Plankton Res., 31, 411-428, doi:10.1093/plankt/fbn124, 2009.

Karl, D. M., Hebel, D. V., Bjorkman, K., and Letelier, R. M.: The role of dissolved organic matter release in the productivity of the oligotrophic North Pacific Ocean, Limnol. Oceanogr., 43, 12701286, 1998.

Killworth, P. D.: The mixing and spreading phases of MEDOC. I, Prog. Oceanogr., 7, 59-90, 1976.

Kiørboe, T.: Turbulence, phytoplankton cell size, and the structure of the pelagic food webs, Adv. Mar. Biol., 29, 1-72, 1993.

Krom, M. D., Kress, N., Brenner, S., and Gordon, L. I.: Phosphorous limitation of primary productivity in the eastern Mediterranean Sea, Limnol. Oceanogr., 36, 424-432, 1991.

Krom, M. D., Emeis, K. C., and Van Cappellen, P.: Why is the Eastern Mediterranean phosphorus limited?, Prog. Oceanogr., 85, 236-244, 2010

Lancelot, C.: Factors affectig phytoplankton extracellular release in the Southern Bight of the North Sea, Mar. Ecol. Prog. Ser., 12, 115-121, 1983.

Lemée, R., Rochelle-Newall, E., Wambeke, F. V., Pizay, M.-D., Rinaldi, P., and Gattuso, J.-P.: Seasonal variation of bacterial production, respiration and growth efficiency in the open NW Mediterranean Sea, Aquat. Microb. Ecol., 29, 227-237, doi:10.3354/ame029227, 2002.

López-Sandoval, D. C., Marañón, E., Fernández, A., González, J., Gasol, J. M., Lekunberri, I., Varela, M., Calvo-Díaz, A., Morán, X. A. G., Álvarez-Salgado, X. A., and Figueiras, F. G.: Particulate and dissolved primary production by contrasting phytoplankton assemblages during mesocosm experiments in the Ria de Vigo (NW Spain), J. Plankton Res., 32, 1231-1240, doi:10.1093/plankt/fbq045, 2010.

López-Urrutia, A., and Morán, X. A. G.: Resource limitation of bacterial production distorts the temperature dependence of oceanic carbon cycling, Ecology, 88, 817-822, 2007.

Mague, T. H., Friberg, E., Hughes, D. J., and Morris, I.: Extracellular release of carbon by marine phytoplankton; a physiological approach, Limnol. Oceanogr., 25, 262-279, 1980.

Marañón, E., Cermeño, P., Fernández, E., Rodríguez, J., and Zabala, L.: Significance and mechanisms of photosynthetic production of dissolved organic carbon in a coastal eutrophic ecosystem, Limnol. Oceanogr., 49, 1652-1666, 2004.

Marañón, E., Cermeño, P., and Pérez, V.: Continuity in the photosynthetic production of dissolved organic carbon from eutrophic to oligotrophic waters, Mar. Ecol. Prog. Ser., 299, 7-17, 2005.

Marty, J.-C., Chiavérini, J., Pizay, M.-D., and Avril, B.: Seasonal and interannual dynamics of nutrients and phytoplankton pigments in the western Mediterranean Sea at the DYFAMED timeseries station (1991-1999), Deep Sea Research Part II: Topical Studies in Oceanography, 49, 1965-1985, 2002.

Maske, H. and García-Mendoza, E.: Adsorption of dissolved organic-matter to the inorganic filter substrate and its implication for C-14 uptake measurements, Appl. Environ. Microbiol., 60, 3887-3889, 1994.

Millot, C.: Circulation in the Western Mediterranean Sea, J. Marine
Syst., 20, 423-442, 1999.

Millot, C. and Taupier-Letage, I.: Circulation in the Mediterranean Sea, in: The Mediterranean Sea, Springer-Verlag Berlin Heidelberg, Germany, 29-66, 2005.

Morán, X. A. G. and Estrada, M.: Short-term variability of photosynthetic parameters and particulate and dissolved primary production in the Alboran Sea (SW Mediterranean), Mar. Ecol.Prog. Ser., 212, 53-67, 2001.

Morán, X. A. G. and Estrada, M.: Phytoplanktonic DOC and POC production in the Bransfield and Gerlache Straits as derived from kinetic experiments of 14C incorporation, Deep Sea Research Part II: Topical Studies in Oceanography, 49, 769-786, 2002.

Morán, X. A. G., Gasol, J. M., Arin, L., and Estrada, M.: A comparison between glass fiber and membrane filters for the estimation of phytoplankton POC and DOC production, Mar. Ecol.-Prog. Ser., 187, 31-41, 1999.

Morán, X. A. G., Taupier-Letage, I., Vázquez-Domínguez, E., Ruiz, S., Arin, L., Raimbault, P., and Estrada, M.: Physicalbiological coupling in the Algerian Basin (SW Mediterranean): Influence of mesoscale instabilities on the biomass and production of phytoplankton and bacterioplankton, Deep Sea Research Part I: Oceanographic Research Papers, 48, 405-437, 2001.

Morán, X. A. G., Estrada, M., Gasol, J. M., and Pedrós-Alió, C. Dissolved primary production and the strength of phytoplankton bacterioplankton coupling in contrasting marine regions, Microb. Ecol., 44, 217-223, 2002.

Morel, A. and André, J.-M.: Pigment Distribution and Primary Production in the Western Mediterranean as Derived and Modeled From Coastal Zone Color Scanner Observations, J. Geophys. Res., 96, 12685-12698, doi:10.1029/91jc00788, 1991.

Moutin, T. and Raimbault, P.: Primary production, carbon export and nutrients availability in western and eastern Mediterranean Sea in early summer 1996 (MINOS cruise), J. Marine Syst., 3334, 273-288, 2002.

Moutin, T., Wambeke, F. V., and Prieur, L.: Introduction to the Biogeochemistry from the Oligotrophic to the Ultraoligotrophic Mediterranean experiment: the BOUM program, Biogeosciences Discuss., in preparation, 2010.

Myklestad, S.: Production of carbohydrates by marine planktonic diatoms. II. Influence of the ratio in the growth medium on the assimilation ratio, growth rate, and production of cellular and extracellular carbohydrates by Chaetoceros affinis var. willei (Gran) Hustedt and Skeletonema costatum (Grev.) Cleve, J. Exp. Mar. Biol. Ecol., 29, 161-179, 1977.

Myklestad, S. and Haug, A.: Production of carbohydrates by the marine diatom Chaetoceros affinis var. willei (Gran) Hustedt. I. Effect of the concentration of nutrients in the culture medium, J. Exp. Mar. Biol. Ecol., 9, 125-136, 1972.

Nagata, T.: Production mechanisms of dissolved organic matter, in: Microbial Ecology of the oceans, edited by: Kirchman, D. L., Wiley-Liss, New York, USA, 121-152, 2000.

Obernosterer, I. and Herndl, G. J.: Phytoplankton extracellular release and bacterial-growth dependence on the inorganic N-P ratio, Mar. Ecol. Prog. Ser., 116, 247-257, 1995.

Puddu, A., Zoppini, A., Fazi, S., Rosati, M., Amalfitano, S., and Magaletti, E.: Bacterial uptake of DOM released from Plimited phytoplankton, FEMS Microbiol. Ecol., 46, 257-268, doi:10.1016/s0168-6496(03)00197-1, 2003.

Pugnetti, A., Armeni, M., Camatti, E., Crevatin, E., Dell'Anno, 
A., Del Negro, P., Milandri, A., Socal, G., Umani, S. F., and Danovaro, R.: Imbalance between phytoplankton production and bacterial carbon demand in relation to mucilage formation in the Northern Adriatic Sea, Sci. Total Environ., 353, 162-177, 2005.

Pujo-Pay, M., Conan, P., Oriol, L., Cornet-Barthaux, V., Falco, C., Ghiglione, J.-F., Goyet, C., Moutin, T., and Prieur, L.: Integrated survey of elemental stoichiometry $(\mathrm{C}, \mathrm{N}, \mathrm{P})$ from the Western to Eastern Mediterranean Sea, Biogeosciences Discuss., 7, 73157358, doi:10.5194/bgd-7-7315-2010, 2010.

Raven, J. A.: Small is beautifull: The Picophytoplankton, Funct. Ecol., 503-513, 1998.

Teira, E., Pazó, M. J., Serret, P., and Fernández, E.: Dissolved organic carbon production by microbial populations in the Atlantic Ocean, Limnol. Oceanogr., 46, 1370-1377, 2001.

Thingstad, T. F., Zweifel, U. L., and Rassoulzadegan, F.: P limitation of heterotrophic bacteria and phytoplankton in the northwest Mediterranean, Limnol. Oceanogr., 43, 88-94, 1998.

Thomas, J. P.: Release of dissolved organic matter from natural populations of marine phytoplankton, Mar. Biol., 11, 311-323, 1971.

Tréguer, P., and Le Corre, P.: Manuek d' analyse des sels nutitifs dans l'eau de mer, Laboratoire d' Oceanographie Chimique, Univ. Bretagne Occidentale, Brest, France, 1975.
Van Wambeke, F., Goutx, M., Striby, L., Sempere, R., and Vidussi, F.: Bacterial dynamics during the transition from spring bloom to oligotrophy in the northwestern Mediterranean Sea: relationships with particulate detritus and dissolved organic matter, Mar. Ecol. Prog. Ser., 212, 89-105, 2001.

Van Wambeke, F., Catala, P., and Lebaron, P.: Relationships between cytometric characteristics of high and low nucleicacid bacterioplankton cells, bacterial production and environmental parameters along a longitudinal gradient across the Mediterranean Sea, Biogeosciences Discuss., 7, 8245-8279, doi:10.5194/bgd-7-8245-2010, 2010.

Wood, A. M. and Van Valen, L. M.: Paradox lost? On the release of energy rich compounds by phytoplankton, Mar. Microb. Food Webs, 4, 103-116, 1990.

Wood, E. D., Armstrong, F. A., and Richards, F. A.: Dtermination of nitrate in sea water by cadmium cooper reduction to nitrite., J. Mar. Biol. Assoc., 47, 23-31, 1967.

Yentsch, C. S. and Menzel, D. I.: A method of the determination of phytoplankton, chlorophyll and phaeophytin by fluorescence, Deep-Sea Res. Pt. I, 10, 221-231, 1963. 